INTERNATIONAL JOURNAL OF RESEARCHES IN BIOSCIENCES, AGRICULTURE AND TECHNOLOGY (C) VISHWASHANTI MULTIPURPOSE SOCIETY (Global Peace Multipurpose Society) R. No. MH-659/13(N) www.vmsindia.org

\title{
STUDY OF BIOCHEMICAL ANALYSIS WITH REFERENCE TO THE NUTRITIVE VALUE OF FISH CIRRHINUS MRIGALA AFTER EXPOSURE TO THE PHYTOTOXIN FROM LASIOSIPHON ERIOCEPHALUS
}

\author{
S. A. Nayakawadi ${ }^{1}$, R. G. Patil ${ }^{2}$, S. G. Nanaware ${ }^{2}$ and M. P. Gujar ${ }^{2}$ \\ ${ }^{1}$, Krantisinha Nana Patil College, Walwa \\ ${ }^{2}$,Lal Bahadur Shastri College, Satara. \\ ramraopati121@yahoo.com
}

\begin{abstract}
:
Cirrhinus mrigala is an important edible freshwater fish. The amount of biochemical constituents such as protein, lipid and glycogen in fishes is used for the determination of their nutritive value of the fish. The fresh water fish Cirrhinus mrigala when exposed to the sublethal concentration $(79.90 \mathrm{ppm})$ of plant toxin from Lasiosiphon eriocephalus, significant decrease in total protein, lipid and glycogen content of liver, muscle and kidney was observed after $96 \mathrm{hrs}$ of exposure period. Maximum decrease in the amout of calories was recorded as $16.92 \%$, $16.96 \%$ and $13.14 \%$ respectively in liver, muscle and kidney of the fish Cirrhinus mrigala. The results were discussed on the basis of metabolism in the fish.

Keyw ords - Fish, Nutritive Value, Phytotoxin
\end{abstract}

\section{Introduction:}

In India biochemical constituents of fishes have been analyzed mainly for the nutritive value of fishes Anon (1962). The fish $C$. mrigala in a commercially important freshwater fish due to its food value. The effect of factory effluent and synthetic chemicals including pesticides, detergents and fertilizers on the biochemical constituents was studies by many investigators (Radhai et. al; 1987, Murthy and Devi; 1982, Bengeri and Patil; 1986, Baigh et al, 1991; Deoray and Wagh, 1991 and Somanath, 1991, Chandravathy and Reddy, 1994). However reports on the effect of phytotoxins on the biochemical constituents are mere. Hence, the present paper reports, studies on the effect of phytotoxin from Lasiosiphon eriocephalus on protein, lipid and glycogen content of liver, muscle and kidney of commercially important fresh water fish C.mrigala.

\section{Material and Methods:}

Healthy adults of fish C.mrigala with average length $9 \pm 2 \mathrm{cms}$. and average wt. $12 \pm 2$ gms. were collected from the local tank Dhom in Satara district (Maharashtra). These fishes were acclimated to the ambient laboratory conditions, for seven days by holding them in large glass containers in chlorine free water. During acclimation fishes were feed by standard fish diet every day. The leaves of $L$. eriocephalus were

collected, air dried and powdered mechanically. This powder was then extracted in ethanol by using Soxhlet's apparatus. The ethanol extract of fruits of $L$. eriocephalus was dried in vaccum desicators.

Twenty fishes were exposed to the sublenthal concentration (79.90 ppm) of ethanol extract of leaves of $L$. eriocephalus. A control set was maintained. After intoxication for $96 \mathrm{hrs}$, two fishes were taken out and stunned to death. A fish was dissected to separate, Liver, Kidney and Muscle tissues. Then all tissues were rinsed in water and kept in petridishes at 00C.Then tissues were weighed and used for biochemical analysis. Proteins, glycogen and lipid were estimated by method of Lowry (Lowry et al, 1951), Caroll method (Caroll et al, 1956), and Folch method (Folch et al, 1957) respectively.

The average values in Calories or Kilo Calories (c) obtained per gram of the tissues have been given as Glycogen $=3.60$, Proteins $=4.10$ and Lipids $=9.30$. These values were used for the calculation of Cal / 100 gms.

\section{Result and Discussion:}

Fishes C. mraigala when exposed. to the sublethal conc. (79.90 ppm) of phytotoxin from fruits of L.eriocephalus for 96 hrs showed decreased level of the proteins, glycogen and lipids in Liver, Kidney and muscle (Table No. 1) Observations on percentage decrease in the values of proteins, glycogen and lipids are also shown in the Table No. 1. Total proteins were decreased by $17.40 \%, 18.31 \%$ and $14.54 \%$ in liver, Muscle and Kidney respectively. Depletion in the glycogen content of liver, muscle and kidney was recorded as $20.20 \%, 21.78 \%$ and $19.12 \%$ respectively. While lipid values were also depleteted by $15.00 \%, 12.41 \%$ and $5.32 \%$ respectively in liver, muscle and kidney. Total percentage decrease in the calories of the liver, muscle and kidney of the intoxicated C. mrigala was found as $16.92 \%, 16.96 \%$ and $13.14 \%$. 
Such type of decrease in the level of protein, glycogen and lipid was reported by Mcleay and Brown (1974) in Juvenile coho, Radhai et al, (1987) in I. mossambica, and Reddy
(1994) in A. scandens after exposure to the kraft pulp mill effluent, heptachlor, nuvacron, tannic acid and lead nitrate respectively.

Table. 1- Alteration in the nutrients in some organ of C.mrigala, after exposure to the plant toxin from L. eriocephalus, for $96 \mathrm{hrs.}$

\begin{tabular}{|c|c|c|c|c|c|c|c|}
\hline \multirow{2}{*}{$\begin{array}{l}\text { Tissu } \\
\mathrm{e}\end{array}$} & \multirow{2}{*}{$\begin{array}{l}\text { Biochemical } \\
\text { constituent }\end{array}$} & \multirow[t]{2}{*}{ Control(mg/gm) } & \multirow{2}{*}{$\begin{array}{l}\text { Intoxicated } \\
\text { (mg/gm) }\end{array}$} & \multirow{2}{*}{$\begin{array}{l}\% \\
\text { decrease }\end{array}$} & \multicolumn{3}{|c|}{ Calories (Cal/ 100gm) } \\
\hline & & & & & Control & Intoxicated & $\begin{array}{l}\% \\
\text { decreas } \\
\text { e }\end{array}$ \\
\hline \multirow{3}{*}{ Liver } & Glycogen & $71.50 \pm 1.32$ & $57.06 \pm 1.32$ & 20.20 & \multirow{3}{*}{137.589} & \multirow{3}{*}{114.308} & \multirow{3}{*}{16.92} \\
\hline & Proteins & $136.18 \pm 1.21$ & $112.48 \pm 1.21$ & 17.40 & & & \\
\hline & Lipids & $61.00 \pm 1.22$ & $51.85 \pm 1.22$ & 15.00 & & & \\
\hline \multirow{3}{*}{$\begin{array}{l}\text { Muscl } \\
\mathrm{e}\end{array}$} & Glycogen & $33.11 \pm 0.60$ & $25.90 \pm 0.60$ & 21.78 & \multirow{3}{*}{89.335} & \multirow{3}{*}{74.185} & \multirow{3}{*}{16.96} \\
\hline & Proteins & $123.12 \pm 0.94$ & $100.58 \pm 0.94$ & 18.31 & & & \\
\hline & Lipids & $29.32 \pm 1.00$ & $25.68 \pm 1.00$ & 12.41 & & & \\
\hline \multirow{3}{*}{$\begin{array}{l}\text { Kidne } \\
\mathrm{y}\end{array}$} & Glycogen & $11.40 \pm 0.92$ & $9.22 \pm 0.92$ & 19.12 & \multirow{3}{*}{71.271} & \multirow{3}{*}{61.904} & \multirow{3}{*}{13.14} \\
\hline & Proteins & $132.98 \pm 0.83$ & $113.65 \pm 0.83$ & 14.54 & & & \\
\hline & Lipids & $13.72 \pm 0.87$ & $12.99 \pm 0.87$ & 5.32 & & & \\
\hline
\end{tabular}

$\pm \mathrm{SD}, \mathrm{P}<0.05$

According to Umminger (1997) the protein is the energy source to spare during the stress conditions. Sastry (1979) was of the opinion that decrease in protein level might be due to increased proteolytic activity, while Dudhat and Bapat (1984) reported that protein level in tissue may decreased due to anaerobic conditions produced by pesticide stress.

Stress.

Umminger (1977) also stated that carbohydrate represents immediate and principal energy source for fishes exposed to stress conditions. Bakthavashsalam and Reddy (1983) reported that glycogen is utilized for energy production to meet higher energy demands to counteract pesticide stress.

Roe and Rao (1981) concluded that decrease in the level of lipid might be due to its utilization to meet the additional energy requirement under stress, while Rao et al, (1985) claimed that lipids might be hydrolyzed to overcome pesticide stress.

From the above discussion and present findings it is concluded that under stress condition caused by phytotoxin from fruits of $L$. eriocephalus fish required additional energy, which is obtained from metabolism of proteins, glycogen and Lipids, which further results in the decrease in protein, glycogen and lipid contents of different tissues of fish C. mrigala. Moreover it is also concluded that depletion in protein, glycogen and lipids decreases the nutritive value of the fish.

Amount of calories in the form of energy obtained from food decides the nutritive value of the any food. In our investigation after intoxication of the fish C.mrigala, the amount of glycogen, proteins and lipids were found decreased in the liver, muscles and kidney of the fishes, due to which amount of calories in the form of energy obtained from these nutrients get reduced. The reduction in the calories resulted in the decrease in the nutritive value of the fishes. Similar results were obtained by (Pisca et al, 1992). Hence it is concluded that piscicide from $L$. eriocephalus is the cause behind the reduction in the nutritive value of the fish C.mrigala.

\section{References:}

[1] Anon (1962) the Wealth of India, Raw material of Vol. IV Supplement fish and Fisheries : Council of Scientific and Industrial Research, New Delhi 1932.

[2] Baigh MD. Azar, Josef Vijayk Rao K. Jayantha (1991) Effect of heptachor on selected Biochemical aspects in the functionally different muscles of $\mathrm{C}$. punctatus, J. Environ Biol 12 (4), 341-345.

[3] Bakhavashsalam R. and Y. Srinivasa (1983) Intoxication effects of lindane (rBHC) on the carbohydrate metabolism in the climbing perch Anabas testudineus (Bloch). Pesticide Bio-Chemistry and Physiology, 20, 340-346.

[4] Bengeri K. V. and Patil H. S. (1986) Respiration, Liver glycogend and 
bioaccumlation in L. rohita exposed to Zinc. Ind. J. com. Anim Physio, 4 (2), 79-84.

[5] Carroll. N. V., R,. W. Longely and J. H. Ros. (1956) The determination of glycogen in liver and muscle by use of anthrone reagent. J. Biol. Chem. 220, 583.

[6] Chandravathy V. Mary and Reddy S.L.N. (1994) In Vivo recovery of protein metabolism in gill and brain of a fish water fish A. Scadens after exposure to lead nitrate. J. Biol. Chem 220, 583.

[7] Deory B. M. and wagh S. B. (1991) Effect thiodon on muscle contents of cypridnid fish B. bendelisis (Ham) J. environ. Biol. 12 (3), 307-312.

[8] Dudhat, I. N. and S. S. Bapat (1984) Influence of eklux on the organic reserves of C. gachua (Ham). In : Assessment of Environmental Pollution (Eds : R. C. Delela $\&$ U. H. Mane). The Academy of Environmental Biology, Muzaffaranager, 120-134).

[9] Folch, J. I., Ascoli, M. Less, J. A. Meath and F. N. L. C. Baran. (1951) Preparation of lipid extract from brain tissue J. Biol. Chem. 191, 833.

[10] Lowry, D. H., N. J. Rosebrough, A. L. Farr and R. J. Randal. (1951) Protein measurement with folin phenol reagent, $J$. Biol. Chem. 1993, 265-275.

[11] Pisaca R. S. Waghray, Sarala and Devi, Indira. (1992) The effect of sublethal cone. Of synthetic Pyrethroid, cypermethrin to common carp. C. Carpio (linn) fry, J. Ennison, Biol, 13, 89-94.

[12] Mcleay, D. J. and D. A. Brown. (1974) Growth stimulation and bio-chemical changes in juvenile coho salmon (O.Kisutch) expose to bleached kraft pulpmil effluent for 200 days. J. Fish. Res. Board. can. 31, 4043-1049.

[13] Murthy, A. S. and A. P. Dalvi. (1982) The effect of endosulfan and its isomers on tissue proteins, glycogen and lipids in the fish channa. Punctatus. Pesticide Biochem. Physiol. 17, 280-286.

[14] Radhaiah, V., M. Girija and Jayantha Rao. (1987) Changes in selected biochemical parameters in the kidney and blood of the fish. T. mossambica, expose to Heptachlor. Bull Environ, Conta. Toxicol, 39, 1006-1011.

[15] Rao, K. S. P. and K. R. S. S. Rao., I. K. A. Sahib and K. V. Rao. (1985) Combined action of carbaryl and phenthoate on tissue lipid devivatives of mussel. C. punctatus (Bloch). Ecotoxicol. Environ SAF. 9 (10, 107111).

[16] Roe, J. R. and V. R. Rao. (1981) Lipid derivaties in the tissues of fresh Water teleost S. mossambicus (Peters) effects of methyl parathion. Proc. ind. Natl. Sci. Acad. 47, 53-57.

[17] Sastry, K. V., P. K. Gupta and P. V,. Malik. (1979) A comparative study of the effect of acute and chronic mercuric chloride treatment on the activities of a few digestive enzymes of a telcost fish. C. Punctatus. Bull. Environ. Contam. Toxico. 22, 28-34.

[18] Sastry K. V. and Dasgupta aradhana. (1991) Effect of acute sublethal concentration of tannic acid on the protein carbohydrate and lipid levels in the tissue of the fish L. rohita J. environ Biol. 12 (2), 107112.

[19] Umminger. B. L. (1970) Physiological studies on super cooled Hill fish $F$. heteroclistus. III Carbohydrate metabolism and survival at sub zero temperature. $J$. Exp.Zool. 173, 159 -174. 